\title{
A Case of Impalement Injury in the Head and Neck
}

\author{
Tatsuya Furukawa, Naoki Otsuki, Hidetoshi Matsui and Ken-ichi Nibu
}

Impalement injuries of the head and neck are extremely rare. We report herein on a 62 -year-old man with an impalement injury in the head and neck region from the branch of a tree. He fell into a ditch and a tree branch penetrated through his left cheek to the posterior region of his neck. Contrast enhanced CT showed that it had penetrated through the parotid gland and passed near the retromandibular vein. The tree stick was successfully removed under general anesthesia without cervical incision. Although a salivary fistula occurred temporally after removal, no other sequela was observed. Preoperative contrast enhanced CT is useful to prevent complications in removal of foreign bodies in the parotid gland.

Keywords : impalement injury, parotid gland, tree stick

\section{References}

1) Madelung OW : Ueber eine typische Forum von Pfähulungsverletzung des Unterleibs. Deut Med Wschr 16: 4-5, 1890.

2) 安田和弘：杙創. 救急医 14:1528-1529, 1990.

3）梅田裕之, 水野修吾, 黒田久弥, 他 : 杙創による直腸穿孔 の 1 例. 手術 55: 595-598, 2001.

4) 飛田忠道, 三上喜久, 村上秀和, 他 : 無自覚の頸部木片異 物の 1 例. 耳鼻・頭頸外科 78: 69-72, 2006 .

5) Nasu T, Koike S, Suzuki Y, et al. : The usefulness of helical CT in the diagnosis of a cervical wooden foreign body: a case report. Pract Otol (Kyoto) 97: 819-824, 2004.

6）河原 康, 堀田文雄, 遠矢東誠, 他：咬筋内植物性異物の 1 例 CT および MRI 所見について. 愛知学院大歯会誌 39: 193-197, 2001.

7) Aoyagi $Y$, Okubo H, Nomura M, et al. : A case of impalement injury. Pract Otol (Kyoto) 100: 765-768, 2007.

8）佐藤宏樹, 小川武則, 志賀清人, 他: 耳前部より総頸動脈 分岐間を通り,下咽頭に穿通した杜創の 1 例. 頭頸部外 20 ： 135-139, 2010.

9）吉原俊雄：唾液腺外傷. JOHNS 9：1361-1363, 2009.

10）宮下仁良, 関口正太郎, 石川雅洋, 他：刺傷により生じた 側頭骨外顔面神経麻痺の 1 例. Facial Nerve Res 25: 124126, 2005.

11) Van Sickels JE : Parotid duct injuries. Oral Surg Oral Med Oral Pathol 52: 364-367, 1981.

12) Lewis G and Knottenbelt JD : Parotid duct injury: is immediate surgical repair necessary? Injury 22: 407-409, 1991.

13) Steinberg MJ and Herréra AF : Management of parotid duct injuries. Oral Surg Oral Med Oral Pathol Oral Radiol Endod 99: 136-141, 2005.
Department of Otolaryngology-Head and Neck Surgery, Kobe University Graduate School of Medicine
Corresponding Author Address : Tatsuya Furukawa tatsuyafurukawa0805@yahoo.co.jp 


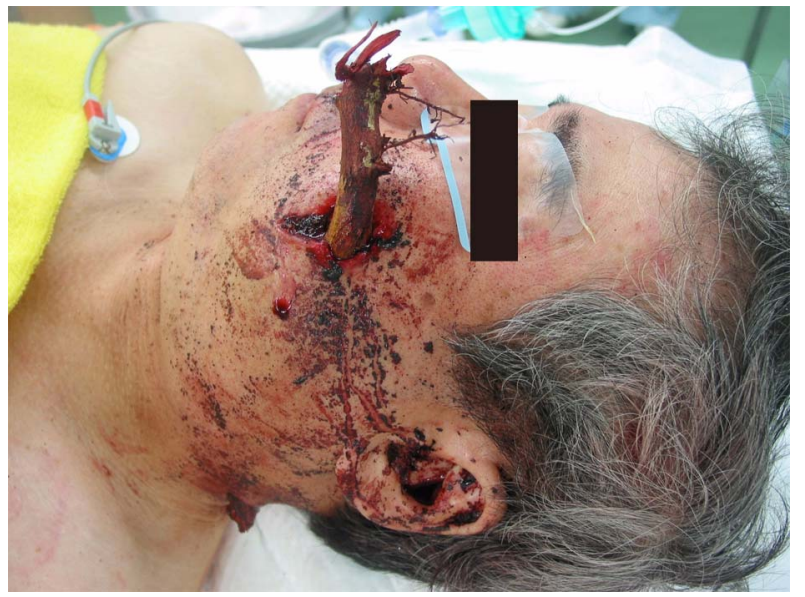

Initial findings

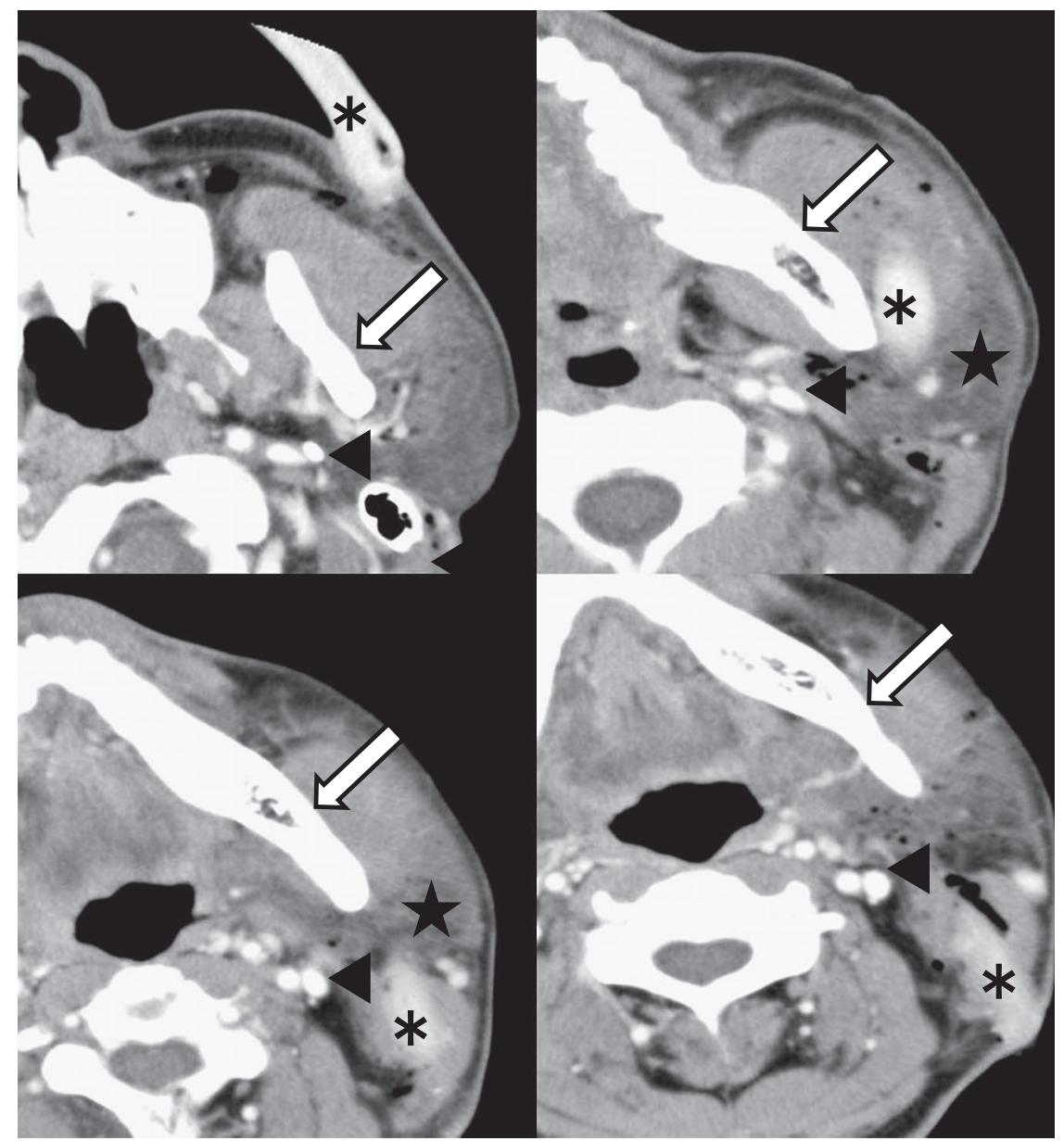

Axial CT scan after enhancement clearly illustrates that the branch $(*)$ passes outside the mandible (white arrow) and penetrates the parotid gland $(\star)$. The common carotid artery and the internal jugular vein $(\mathbf{\Delta})$ have been pushed medial to the branch, and are not damaged. 